\title{
A adaptação na obra aberta como narrativa convergente
}

Resumo: Por intermédio da comparação narrativa do livro Os Sertões (1907) e sua adaptação para o cinema Guerra de Canudos (1997), propomos uma leitura do conceito de Obra Aberta de Umberto Eco. Considerandose que nos processos de adaptação entre os meios de comunicação os sentidos representativos dos personagens são redefinidos, buscamos propor a seguinte questão: Haveria um espaço de representação compartilhada entre as obras, criado pelo processo de adaptação, que se tornam convergentes para caracterização da Guerra de Canudos enquanto narrativa ficcional? Verificou-se as associações discursivas das narrativas, do filme e do livro, por meio da comparação de trechos significativos das obras, apontando a existência para o público de uma multiplicidade de imagens midiáticas do conflito em Canudos enquanto uma realidade ficcional.

Palavras-chave: adaptação cinematográfica; adaptação na obra aberta; narrativa cinematográfica.

\section{La adaptación en la obra abierta como narrativa convergente}

Resumen: A través de la comparación de la narrativa del libro Os Sertões (1907) y su adaptación al cine Guerra de Canudos (1997), se propone una lectura del concepto de trabajo abierta por Umberto Eco. Teniendo en cuenta que en el proceso de adecuación entre los medios de forma representativa los personajes se ponen a cero, tratamos de proponer la pregunta: ¿No habría un espacio compartido de representación entre las obras, creado por el proceso de adaptación, que se convierten convergió para caracterizar la Guerra de Canudos como narrativa de ficción? Hubo las asociaciones discursivas de la narrativa, la película y el libro, a través de la comparación de las partes significativas de las obras, que apunta a la existencia de la opinión pública en una variedad de imágenes de los medios de conflicto en Canudos como una realidad ficticia.

Palabras clave: adaptación de película; daptación como uma obra aberta; película narrativa.
André Campos Silva ${ }^{1}$

${ }^{1}$ Possui graduação em Comunicação Social - Publicidade e Propaganda pelo Instituto Municipal de Ensino Superior de Assis (2005), mestrado em Comunicação pela Universidade de Marília (2008) e doutorado em Ciências da Comunicação pela Universidade do Vale do Rio dos Sinos (2014). Tem experiência na área de Artes, com ênfase em Cinema, atuando principalmente nos seguintes temas: suspense, terror, cinema, cultura e clichê cinematográfico. Atualmente é professor colaborador do curso de Cinema e Vídeo da Universidade Federal da Integração Latino-Americana - UNILA. Também foi professor no Instituto Federal de Santa Catarina - Campus Palhoça, e na Faculdade Pitágoras, tendo lecionado em cursos técnicos, de graduação e pós-graduação. Também ministrou curso de extensão na Universidade Federal de Santa Catarina-UFSC. 


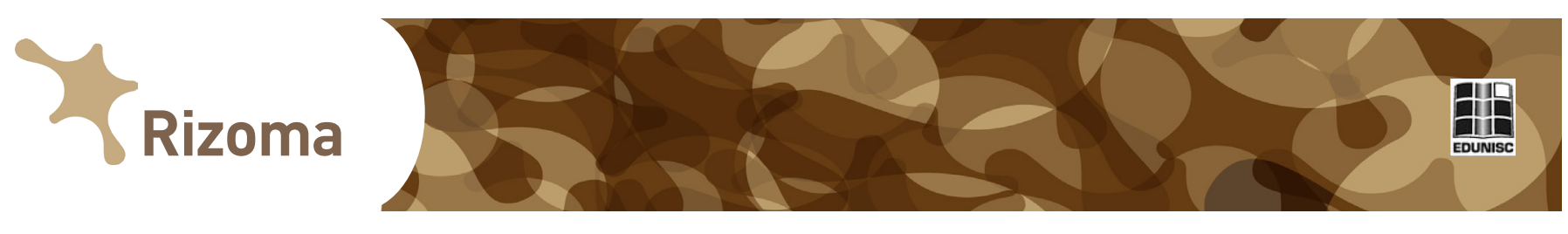

\section{Adaptation in work open as a narrative convergent}

Abstract: Through the narrative comparison of Os Sertões (1907) and his film adaptation Guerra de Canudos (1997), we propose a reading of the concept of Openwork by Umberto Eco. Considering that in the processes of adaptation between the media The representational senses of the characters are redefined, we seek to propose the following question: Would there be a space of shared representation among the works, created by the adaptation process, that converge to characterize the Canudos War as a fictional narrative? The discursive associations of the narratives, the film and the book were verified by comparing significant sections of the works, pointing out the existence for the public of a multiplicity of media images of the conflict in Canudos as a fictional reality.

Keyword: Film adaptation; daptation as a openwork; cinematographic narrative.

\section{Introdução}

No livro Obra Aberta - Forma e indeterminação nas poéticas contemporâneas, Eco (1995) apresenta o conceito de obra aberta. A inspiração do autor é creditada ao romance Ulisses, de James Joyce. Inicialmente, este conceito foi elaborado como um artigo crítico sobre a forma sui generis adotada no romance de Joyce. Posteriormente, Eco amplia sua abordagem, tornando Joyce apenas um dos capítulos explorados no livro homônimo, dotando seu conceito de maior profundidade.

Ele define a obra de arte de vanguarda como algo inacabado que exige do receptor uma participação ativa durante a apreciação estética. O observador é convidado a perceber a obra dentro de um universo de possibilidades interpretativas. Apesar de não ter definido um conjunto específico de obras de arte, o conceito de obra aberta é abrangente por necessidade da articulação teórica. Este conceito diz respeito a um tipo de relacionamento entre as obras e os seus receptores, e não à estrutura objetiva da obra.

Portanto, as indagações a respeito dos trabalhos artísticos realizados devem partir das relações que elas estabelecem como público e sua compreensão. Dessa forma, a obra em si não é o objetivo, mas as relações possíveis criadas desta obra com o mundo. Sendo assim, elementos decorrentes da ambiguidade interpretativa são imperativos para a compreensão destas estéticas, permitindo ao receptor, liberdade de ressignificação contínua do objeto artístico. Sempre que o público fizer uso destas obras, remonta as mesmas segundo suas interpretações, encontrando diversas obras em uma única obra.

Compreendendo o processo de adaptação, entre literatura e cinema, como um mecanismo que gera ressignificação e ambiguidades nas narrativas da obra de origem para a obra adaptada, iremos considerar a estética da adaptação entre obras específicas como resultado de uma 

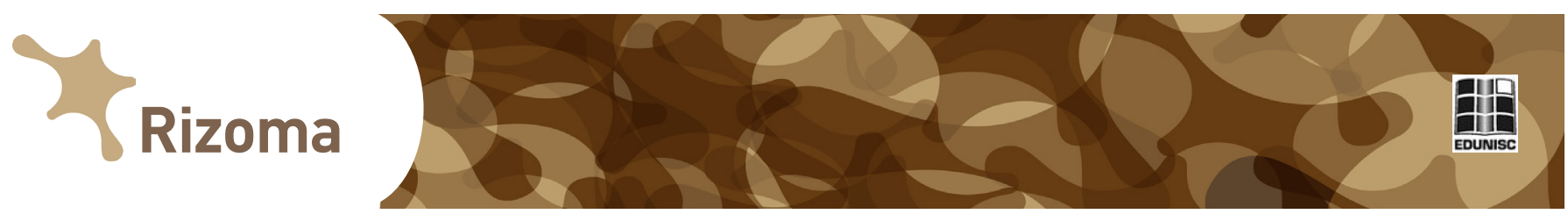

obra aberta. Bem como Os Sertões (1907), de Euclides da Cunha e sua adaptação ao cinema Guerra de Canudos (1997), do diretor Sérgio Rezende, como uma única grande "obra" narrativa, que estabelece distintas conexões interpretativas sobre a narrativa do conflito de Canudos com o público.

Nossa posição pode ser justificada pela passagem de Eco (1992) quando afirma:

\begin{abstract}
Acreditamos ter afirmado suficientemente que a abertura, entendida como ambiguidade fundamental da mensagem artística, é uma constante de qualquer obra em qualquer tempo.[...] Isto porque a análise de um quadro informal ou mesmo um drama de Brecht nada mais visava senão iluminar certo tipo de relação entre obra e fruidor, o momento de uma dialética entre a estrutura do objeto, como sistema fixo de relações, e a resposta do consumidor como livre inserção e ativa recapitulação daquele mesmo sistema. (ECO, 1992, p. 27).
\end{abstract}

Um todo orgânico nasce da fusão de diversos níveis de experiências quando sabemos estar diante de uma obra já conhecida e adaptada entre meios diferentes. A dialética da fruição proposta por Umberto Eco nasceria não de uma obra, mas do conjunto das obras adaptadas, quando conhecidas pelo espectador/leitor. Desta maneira, a adaptação seria "uma obra realizada, ponto de chegada de uma produção e ponto de partida de uma consumação que - articulando-se - volta a dar vida, sempre e de novo, à forma inicial, através de perspectivas diversas" (ECO, 1992, p. 28).

Hoje, são muito comuns livros que se tornaram famosos por conta de suas adaptações cinematográficas acabarem sendo re-editados contendo capas de elementos das narrativas cinematográficas adaptadas. Segundo Serge (2005), do ponto de vista comercial, é mais vantajoso comercializar histórias que já tenham um público. Este processo de aproximação diegética entre obras pode ser visto como parte do fenômeno da adaptação na obra aberta como narrativa convergente. Isto porque o conceito de convergência midiática proposto por Jenkins (2008) depende da interação entre o produtor de mídia e a participação ativa dos consumidores com estas narrativas.

Por convergência, refiro-me ao fluxo de conteúdos através de múltiplas plataformas de mídia, à cooperação entre múltiplos mercados midiáticos e ao comportamento migratório dos públicos dos meios de comunicação, que vão a quase qualquer parte em busca das experiências de entretenimento que desejam. (JENKINS, 2008, p. 29).

Na convergência tradicional proposta pelo pesquisador, a circulação das narrativas depende das táticas de apropriação popular. Neste sentido, a trilogia da saga "Guerra nas Estrelas" está presente em diversos filmes, livros e jogos. Cada uma das obras se relaciona e conta uma parte da narrativa. Outro exemplo é o filme "Nem Sansão nem Dalila" (1951), que buscou fazer uso de uma narrativa compartilhada dos personagens entre os estúdios 

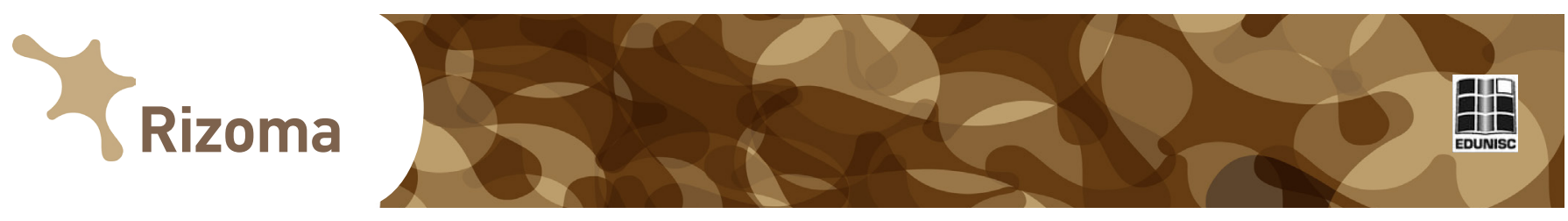

brasileiros de rádio e o filme. O prestígio e alcance que o rádio detinha com as classes mais populares foi utilizado para permitir ao filme obter sucesso na bilheteria. Entretanto estes exemplos são apenas simples convergência narrativa fechada, entre o rádio e o cinema, entre o cinema, jogos e livros. Aqui, buscamos expor uma problemática um pouco diferente, onde a convergência narrativa ocorreria justamente por considerar o processo de adaptação como uma obra aberta.

Para a condução metodológica, consideraram-se a estrutura das estórias como um conjunto de traços partilhados entre as diferentes obras, e os elementos distintos de cada narrativa; foram selecionados trechos significativos das obras, que permitiram articulações de oposição e aproximação entre ambas narrativas, para posterior comparação e discussão de seus conjuntos de traços.

\section{A adaptação como forma aberta}

Estamos a todo o momento tomando contato com releituras de obras originalmente criadas para fins e meios de comunicação diferentes daqueles a que foram destinadas. Adaptar, segundo Field (2001, p. 174), "significa transpor de um meio para outro. A adaptação é definida como a habilidade de "fazer corresponder ou adequar por mudança ou ajuste"'.

Quando uma narrativa é adaptada para outro meio, ela sofre um processo interpretativo, criando um novo objeto estético. A esse respeito, Rizzo (2007, p. 22) diz:

\footnotetext{
Muito mais do que uma escolha de palavras ou signos que correspondam uns aos outros, a adaptação cinematográfica pressupõe uma série de escolhas, como quais trechos de texto devem ser mantidos inalterados em sua superfície linguística; quais partes da fábula do original devem ser alteradas e quais devem permanecer intactas; por quem e de que forma as palavras escolhidas serão ditas ou transmitidas, qual será a iluminação no momento, de qual ângulo tal momento será observado e por quem; enfim, quais partes do conteúdo e dos efeitos de sentido quer-se manter daquele texto original.
}

As especificidades de cada meio impõem de maneira inflexível necessidades de recodificação a um trabalho que visa a ser adaptado. No processo de adaptação entre meios de comunicação diferentes, surgem ambiguidades decorrentes de aspectos dos próprios meios de comunicação, que originalmente não haviam sido contemplados pelo autor da obra original, implicando que durante o processo de adaptação seja remodelado pela nova mídia.

As deficiências causadas por essas lacunas tornam o ato de re-leitura de uma obra original uma atividade de re-criação, pelo processo de elaborar mecanismos narrativos antes inexistentes. Por isso são comuns críticas à adição de novos elementos exteriores à obra original. 


\title{
Sizoma
}

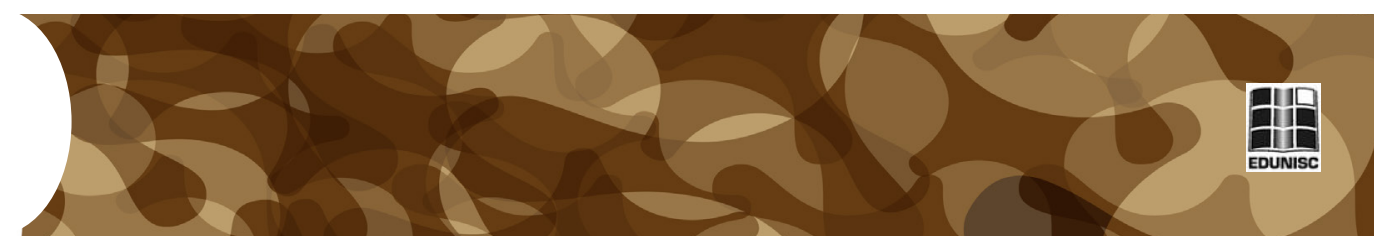

Em uma obra audiovisual, a imagem é um elemento altamente discursivo, sendo incapaz de não preencher o "espaço fílmico" com elementos inexistentes originalmente em um romance literário. Sua tomada de consciência se dá pelas relações imagéticas assumidas entre planos. Segundo Vanoye e Goliot-lété (1994, p. 11), "sua natureza de pluralidade de códigos proíbe pensar em qualquer 'reprodução verbal'". Mourão e Leone (1993, p. 49) ressaltam:

\begin{abstract}
Articulando-se em ordem diferente os mesmos planos, obtém-se um efeito emocional diferente. Admitindo-se isso, parece lícito deduzir que, de um lado, a montagem afeta diretamente as capacidades emocionais do espectador e, de outro, interfere também diretamente na significação do discurso, pois torna relativos os possíveis sentidos absolutos que têm os planos isoladamente.
\end{abstract}

Os mecanismos de produção de sentido são completamente diferentes, porque não só as atuações de personagens, espaços, tempos e objetos se configuram como ações narratológicas em si mesmas, mas é inexistente uma indicação singular de um elemento nominal (isso, aquilo, eu, ela etc.), impossibilitando apontar um único responsável por determinar um discurso interno dentro da obra audiovisual.

A esse respeito, Martin (1963) irá dizer que no cinema são os próprios seres e coisas que falam, sendo um confronto direto entre o signo e a coisa significada, constituindo um único e mesmo ser. Metz (1980) aponta que o discurso cinematográfico deve ser tratado segundo suas especificidades, enquanto discurso significante. $\mathrm{O}$ "ilusionismo" no cinema tende a diminuir os agentes das marcas responsáveis pela produção dos discursos de sentido na obra.

Desta maneira o discurso enquanto síntese da ideia passa a ser o elemento de referência para o intercâmbio entre meios de comunicação diferentes. A manipulação da síntese permite dar uma nova impressão sobre um olhar já conhecido de uma obra, por envolver reinterpretações de discursos. Segundo Xavier (2003),

\footnotetext{
A interação entre as mídias tornou mais difícil recusar o direito do cineasta à interpretação livre do romance ou peça teatral, e admite-se até que ele pode inverter determinados efeitos, propor outra forma de entender certas passagens, alterar a hierarquia dos valores e redefinir o sentido da experiência das personagens. A fidelidade ao original deixa de ser o critério maior de juízo crítico, valendo mais a apreciação do filme como nova experiência que deve ter sua forma, e os sentidos nela implicados, julgados em seu próprio direito. (XAVIER et al, 2003, p. 61).
}

A adaptação entre obras impõe a reinterpretação da narrativa a fim de adequá-la à linguagem de outro meio. Este processo artístico é permeável por intencionalidades, contextos e modos de produção diferentes entre os autores envolvidos em cada uma das obras, por serem compreendidas e executadas por autores diferentes.

A obra literária Os Sertões, publicada em 1907, teve como interesse narrativo o diagnóstico dos acontecimentos da guerra, expondo a vitimização 


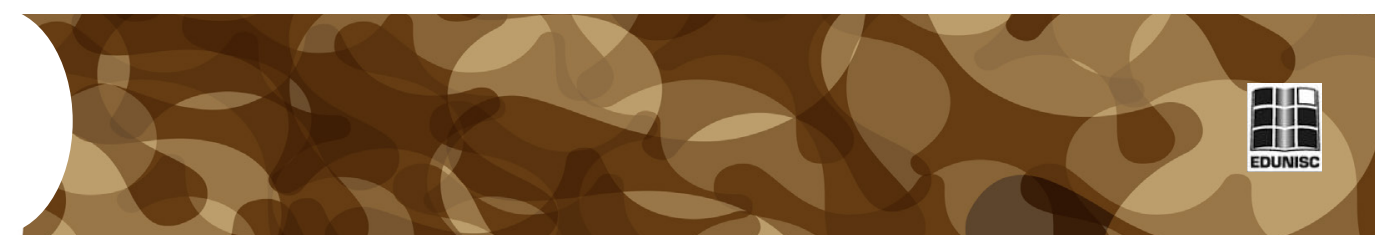

dos soldados das campanhas pelo desconhecimento da região, das condições que a população da região estava exposta, que tem como consequência, o massacre dos "rebeldes". O público ideal para o qual a obra foi direcionada era letrado, de classe média, residente na capital e nas áreas mais desenvolvidas do país; localidades distantes, tanto politicamente como culturalmente, da região do conflito.

Por outro lado, considerando o aporte financeiro para a produção do filme Guerra de Canudos de 1997, dentro do contexto da indústria cultural, a obra assumiu uma conotação deveras distinta. Foi claramente direcionado para a grande população de todo o Brasil, tanto pela maneira de abordar a temática como pelo tratamento recebido. Segundo Cury (1997),

A geração intelectual de 1870, semelhantemente à anterior geração romântica, visa a traçar o perfil do homem brasileiro, só que agora sob a égide da ciência. Segundo as teorias científicas do período, o meio moldaria o homem, que seria um resultado dos condicionamentos do clima, das condições geográficas em geral. Presente na literatura da época, também aqui, para se explicar o atraso, a miséria, o fanatismo religioso, são ressaltados os determinismos: psicológico, geográfico, físico, climático. [...] explicando o indivíduo pelo seu corpo, "medicalizando" a cultura, opondo o homem do sertão ao homem do litoral, já que a raça negra, predominante nos sertões, era considerada inferior e seria destinada somente ao trabalho. O raciocínio decorrente seria que, sob o clima tropical, com um povo miscigenado, não seria possível forma adiantada de organização social, econômica e política, argumento claramente justificador da dominação colonial e dos regimes autoritários. (CURY, 1997, p. 233).

A compreensão que Euclides tinha da sociedade seria reprovada aos olhos da sociedade de hoje se não fosse adaptado, representando um grande problema para obter a simpatia do público. Essa problemática da adaptação de linguagens entre meios é exposta por White (1994, p. 80):

\footnotetext{
O problema da ideologia ressalta o fato de que não há qualquer modo de valor neutro na urdidura do enredo, explicação ou até mesmo descrição de qualquer campo de eventos, quer imaginários ou reais, e sugere que o próprio uso da linguagem implica ou acarreta uma postura específica perante o mundo que é ética, ideológica, ou política de um modo mais geral: não apenas toda interpretação, mas também toda linguagem, é contaminada politicamente.
}

\section{Obra aberta na trama narrativa}

Adaptar narrativas entre meios de comunicação distintos implica estabelecer outros tipos de relações discursivas estéticas entre as estruturas das obras e, com isto, os tipos de vínculos criados entre uma obra "original" e uma adaptada se altera.

Toda obra narrativa possui um "foco narrativo", que é o responsável por tornar perceptíveis os acontecimentos da história, através do narrador. Esses acontecimentos seguem um ponto de vista, normalmente atribuído a um personagem, que é a maneira pela qual são estabelecidas as perspectivas 
da visão da história.

Segundo Aguiar e Silva (1974, p. 293), o foco narrativo "compreende as relações que o narrador mantém com o universo diegético e também com o leitor (implícito, ideal e empírico)". Acerca do efeito produzido pela escolha do foco narrativo, Campos (2007, p. 29) diz:

O narrador de Chinatown poderia ter narrado principalmente o fio da estória de Noah Cross, um homem desprovido de ética e de senso de limite, que seduz e engravida a filha, manipula o sócio para obter corroboração técnica para os seus projetos escusos [...]. Ou o narrador poderia ter narrado principalmente o fio da estória de Evelyn Mulwray, uma mulher aturdida entre o ódio que sente pelo pai-amante, o amor que tem pela filha-irmã e a culpa de, esses anos todos, haver enganado o marido, correto e bom, sobre a paternidade da filha-irmã, e de se ter calado sobre as atividades criminosas do pai. Ou ele poderia ter narrado principalmente o fio da estória de Hollis Mulwray, um mártir da engenharia e da ética, a tentar opor resistência à ganância e à corrupção. [...] Em cada um desses casos, Robert Towne teria selecionado como foco principal da atenção do seu narrador um ponto diferente da mesma massa de estória - e o que decorre disso. Se tivesse selecionado Noah Cross como principal ponto de foco do seu narrador, Robert Towne teria narrado, principalmente, a estória da corrupção e da impunidade na cidade de Los Angeles daqueles anos. Se selecionasse Hollis Mulwray, o narrador teria gerado um libelo político. Selecionasse Evelyn Mulwray como foco principal e ele teria narrado uma estória trágica, com ofensa a tabu do incesto, ofensa a limite, arrogância ("húbris") e a devastação de vidas e almas decorrente disso. Se Towne selecionasse, como selecionou, o detetive J.J. Gittes como principal, o narrador teria narrado, como narrou, o percurso de um homem que passa do desconhecimento para o conhecimento.

Desta forma, percebemos uma unidade difusa de significação construída pelo discurso narrativo, onde a compreensão dos acontecimentos se deve às escolhas estabelecidas pelo autor da trama. Visto que: "Foi do ponto de vista de Dom Casmurro que soubemos da estória de Bentinho e Capitu - e nossa dúvida sobre se Capitu foi adúltera provém da limitação do que Dom Casmurro conseguiu perceber e do que quis nos narrar" (CAMPOS, 2007, p. 47). Segundo Moreira, citado por Suely (2005, p. 25),

Na Teoria da Narrativa, em termos gerais, a focalização muda de acordo com o tipo de narrador que se estabelece para contar a história. Se ele é um personagem, portanto, um narrador de primeira pessoa, podemos, seguramente, afirmar que o olhar sobre a organização dada à história difere muito do olhar de um narrador onisciente, em terceira pessoa, portanto, fora da história.

Sobre este assunto, ainda de acordo com Campos (2007) existem, ao todo, seis pontos de vista onde o narrador pode ser colocado dentro de uma narrativa, sendo eles: onisciente (ou acima da estória), do lado do personagem principal, do lado de personagem secundário, dentro do personagem principal, dentro de personagem secundário e voltado para dentro dele mesmo.

A maneira de trabalhar uma mesma obra permite obter distintas interpretações sobre um mesmo acontecimento narrativo, como é 

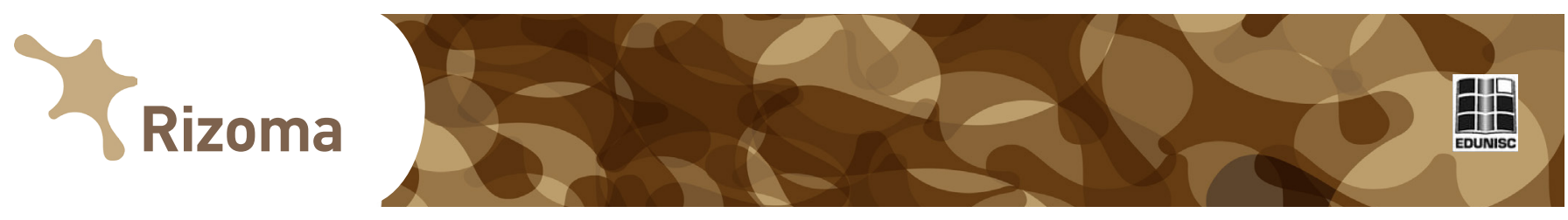

estabelecido pelo conceito da obra aberta de Eco (1992). A esse respeito, Cândido (1969, p. 69) irá dizer: "a natureza da personagem é uma estrutura limitada, obtida não pela admissão caótica de um sem número de elementos, mas pela escolha de alguns elementos organizados segundo uma certa lógica de composição".

Em decorrência destes pressupostos, toda organização de uma obra possui uma intencionalidade exercida por uma visão de mundo, de um determinado processo sócio-histórico determinado no tempo/espaço. A obra ficcional tenta delimitar uma impressão de realismo, ao juntar uma rica quantidade de elementos históricos reais com a experiência ficcional dramatizada da guerra, vivida pelo narrador em terceira pessoa. A escolha do narrador causa uma grande proximidade com o leitor ao descrever suas impressões de profundidade e realismo, assim como se configura como um romance dramático.

Segundo Muir (s/d, p. 21), nesse gênero tanto o enredo como o personagem "[...] são entrelaçados entre si. As qualidades conhecidas dos personagens determinam a ação e a ação, por sua vez, modifica de maneira progressiva os personagens e assim tudo é impelido para diante em direção a um fim $[\ldots] "$ ".

\section{Comparação narrativa entre as mídias livro e filme}

Para Miranda Moreira, citada por Flory (2005), toda narrativa independente da linguagem específica do meio apresenta obrigatoriamente a tipologia: narrador, personagens, tempo, espaço e acontecimentos. Por conta disto, estes serão os elementos utilizados para realizar a comparação.

Os Sertões, antes de tudo, é uma obra híbrida entre narrativa literária e histórica. De um lado, temos a postura do escritor como cientista e, do outro, a intenção artística de construir uma efígie narrativa. A reconstrução dos combates realizada por Euclides teve como base reportagens de outros jornalistas, depoimentos de membros do exército e da comunidade sobrevivente do conflito. Euclides buscou dar forma aos personagens do livro segundo aquilo que percebia como crise social, política e étnica do Brasil.

A organização da narrativa do escritor perpassa por suas concepções republicanas e positivistas da sociedade, evolucionistas e naturalistas do ser humano. Desta maneira, a organização da sua trama narrativa se inicia ao considerar um estudo do meio ambiente, a região geográfica e a raça, para compreender a identidade brasileira do povo sertanejo; assim, considerava as disposições inatas do conflito, para então descrever a movimentação das tropas, as batalhas, os ataques e retiradas em massa. $\mathrm{O}$ sertanejo e o meio ambiente foram dissecados e tratados como membros de um mesmo sistema.

No primeiro capítulo, na primeira parte de Os sertões, intitulado “A 

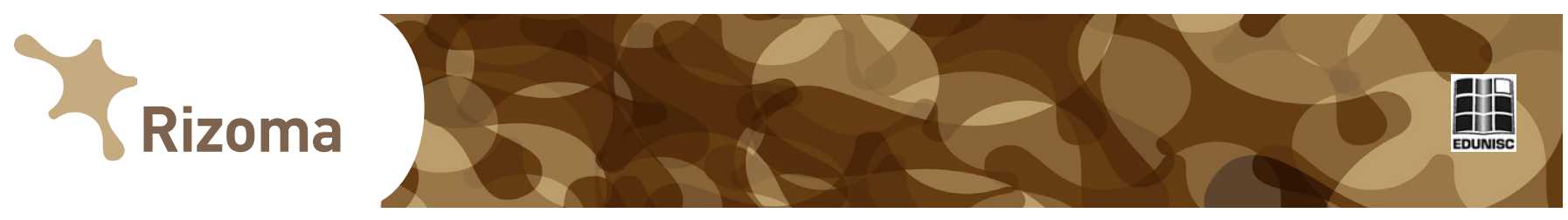

Terra" Euclides descreve o ambiente onde ocorreu o conflito. Além de ser um capítulo dedicado ao ambiente onde ocorrem os acontecimentos, é tido pelo autor como um dos responsáveis pela formação do homem da região do sertão baiano, e por isso assume uma grande relevância que quase se torna um personagem.

$\mathrm{Na}$ segunda parte do livro, o homem enquanto personagem surge aos poucos, enquanto uma massa não identificada, mas generalizada a todos os sertanejos do interior, sinalizando sua ligação com a terra. Apenas na terceira parte, o ambiente se torna secundário, dando espaço para os sertanejos e o conflito.

Para ele, a população vive desamparada em uma região de extrema dificuldade climática, abandonada em meio a crendices e ao atraso social. Sua visão do sertanejo é de uma sub-raça adaptada à região. Por isso a solução apresentada por Euclides para integrar essa raça é modificar o seu meio ambiente e, assim, interferir no processo de adaptação.

É justamente este cenário tão pouco amistoso e sua falta de conhecimento que Euclides irá atribuir como o responsável pelo desastre das expedições militares. A região se torna um inimigo a ser vencido, mais poderoso que os jagunços, pela sua visão desenvolvimentista e modernista.

Desta maneira Euclides inicia a exposição de sua narrativa através de uma discussão do trajeto sobre a geografia pela Região Sul, até chegar ao Nordeste, como forma de estabelecer um contraponto entre os ambientes, avançado socialmente e atrasado. Trata-se de um ambiente desconhecido pela elite da capital, Rio de Janeiro.

O filme do diretor Sérgio Rezende aborda de maneira distinta a compreensão da guerra de Euclides. Ele reelabora todo processo narrativo, desconsiderando essa visão positivista, naturalista e evolucionista do escritor.

O filme é organizado em torno de uma visão política que sintetiza dentro de um núcleo familiar de personagens com diversos problemas sociais do Brasil e do Nordeste da atualidade, já por demais abordados no cinema, como: reforma agrária, a exploração da mão de obra por latifundiários, indústria da seca, luta por direitos iguais entre homens e mulheres, exploração econômica-social, etc.

Diferente de Euclides que buscou contextualizar o ambiente, a geografia, para então introduzir separadamente o homem sertanejo dentro da narrativa da guerra, Rezende parte do pressuposto que o brasileiro atual tem conhecimento destes elementos, já exaustivamente explorados na mídia contemporânea. Por isto, estas adversidades sociais se tornam elementos condutores das ações que os personagens sofrem pelo ambiente social e natural da região, permitindo ao diretor dar mais ênfase a ação propriamente do conflito armado.

Para a realização do filme, foi montada uma cidade cenográfica baseada em registros e relatos históricos. Assim, boa parte das cenas do 


\section{Sizoma}

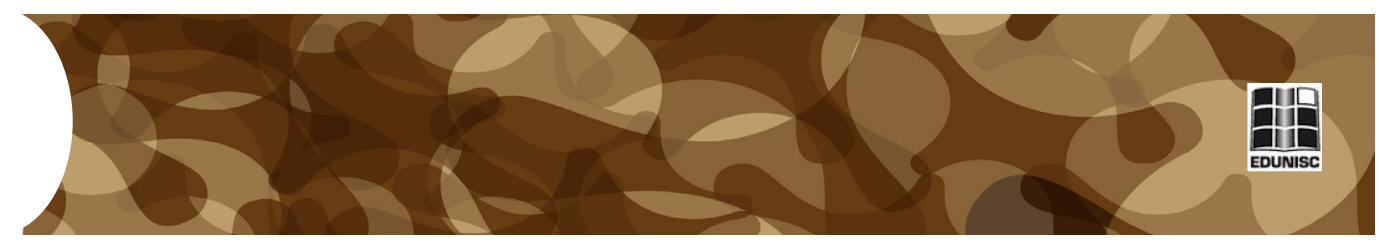

filme são gravações "externas", dando ênfase ao ambiente natural do sertão da Bahia.

A exposição da narrativa inicial do filme faz uma introdução dos dois primeiros capítulos do livro, por intermédio de um longo plano-sequência, com uma câmera realizando um movimento panorâmico. São destacados a geografia acidentada e o clima quente e árido do Nordeste.

A visita ao texto original termina para logo em seguida apresentar uma pequena procissão de Antônio Conselheiro em meio à Caatinga no pôr do sol. Surge um breve texto que rompe completamente com a visão de Euclides sobre os motivos da guerra, porque destaca quem foi Antônio Conselheiro, e que ele se opôs ao governo republicano, para então ser apresentado o título do filme Guerra de Canudos.

A obra de Euclides é muito mais dialética a respeito, porque destaca o ambiente como responsável pelo sofrimento e fracasso das campanhas militares. Portanto, o homem sertanejo no filme não é visto como produto de um ambiente inóspito e adaptado a ele, mas abandonado naquele local pelo governo republicano, que apenas busca cobrar impostos.

Esta afirmação se torna ainda mais relevante, quando consideramos que a falta de conhecimento do terreno inicial no filme não se torna motivo de preocupação ou mesmo necessário para a vitória sobre a "revolta" de Canudos. Além disso, caracteriza Antônio Conselheiro como uma espécie de Robin Hood brasileiro.

Além das questões contemporâneas já citadas, o filme explora em sua narrativa elementos pouco explicitados no livro de Euclides a respeito da comunidade que se formou em Canudos, como a inexistência da posse da propriedade privada dentro do grupo, a divisão do trabalho e da terra. São aspectos que permitem a existência do povo livre da dominação de barões e coronéis.

No livro, a guerra ocorre pela falta de conhecimento para o progresso a respeito da região do sertão baiano. Vitimiza tanto a população daquela região de Canudos, que é massacrada em decorrência de seu atraso social, como também os soldados das companhias que sofrem por sua falta de informação da terra onde se dá o conflito.

No filme, o exército vitimiza a população, que é oprimida pelas políticas governista e pela miséria. Ambas versões colocam o sertanejo como vítima, mas tratam isto de maneira diferente. No livro de Euclides, o exército é apenas um dos fatores que vitimizam a população, o menor deles. Enquanto que no filme, o exército como força republicana é o único fator a ser declarado como antagonista.

Abordar a construção de personagens em nível mais simples em Os Sertões é difícil, em virtude de a caracterização ser difundida sobre todos os sertanejos canudences de maneira por igual, como uma massa amorfa. Os personagens são descritos por meio de relatos. Como o assunto que atrai o foco narrativo é a guerra, e a violência do conflito como produto do ambiente descrito por Euclides, os personagens recebem um tratamento secundário. 

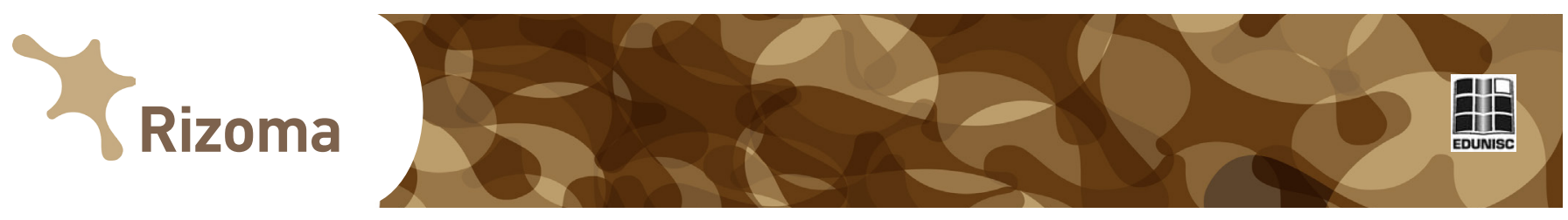

Com raríssimas exceções, alguns personagens recebem destaque em momentos pontuais, mas possuem uma identificação dramática específica. No filme, esse homem sertanejo tem rosto, identidade e nos guia para mostrar o drama da guerra por dentro do arraial de Canudos. Os personagens do filme, em geral, são conformados com a adversidade, a falta de água, a fome e o abandono.

A República tão valorizada por Euclides como representante da ordem e do progresso da sociedade sã, é retratada perante o núcleo da família do filme como a força responsável pela sua destruição por intermédio da cobrança de impostos. O embate pela cobrança dos impostos é a ação inicial que irá desencadear a primeira reação de luta da família no filme, quando o patriarca da família, "Zé", é duramente reaprendido pelas autoridades para realizar o pagamento das contas.

Sérgio Rezende liga este núcleo familiar à guerra por meio da religião messiânica do Antônio Conselheiro, expostos como único disposto por trazer algum tipo de resposta ao sofrimento desta família, impelindo-os a lutar contra a República. Antônio Conselheiro é tido como um louco religioso, ideia bem próxima da desenvolvida por Euclides. Porém, no filme, em virtude de o narrador em diversos momentos ser colocado ao lado do personagem de Antônio Conselheiro, o público pode perceber a existência deste personagem de maneira mais humanizada. Esta estratégia de humanizá-lo se torna ainda mais clara quando o narrador é colocado dentro do personagem após falecer e revelar seus pensamentos, de maneira lúcida.

Uma das estratégias utilizadas no desenvolvimento dramático da narrativa do filme foi tentar colocar um personagem transitando entre o exército republicano e o arraial de Canudos, dramatizando o discurso dos dois lados do front, e propondo uma abordagem que valoriza os sertanejos e as "pessoas comuns".

O narrador fica ao lado dos personagens principais e por esse motivo não existe um único narrador, mas uma visão da estrutura em torno desses personagens. Além disto, o personagem de Luíza acaba por receber o foco principal da história, fazendo com que toda a história se mova a sua volta.

Essa personagem Luíza é a filha mais velha do núcleo familiar. Ao se mostrar contrária em seguir Antônio Conselheiro por considerá-lo louco, ela abandona a família e vai trabalhar como prostituta no povoado local, que fornece a estrutura necessária para o exército combater.

$\mathrm{O}$ fato de escolher uma mulher que se torna prostituta, como foco principal, é por deveras significante dentro deste contexto ficcional. A personagem feminina que não é submissa à sociedade patriarcal, é responsável por conectar o narrador aos dois lados do front.

A escolha pelo ponto de vista muito distante de Euclides, relega esse espaço para uma representação da mulher como algo depreciativo ou menor. Isto se torna ainda mais emblemático se considerarmos que o filme retrata estes personagens em uma região de luta contra a falta de fertilidade do solo. 


\section{Rizoma}

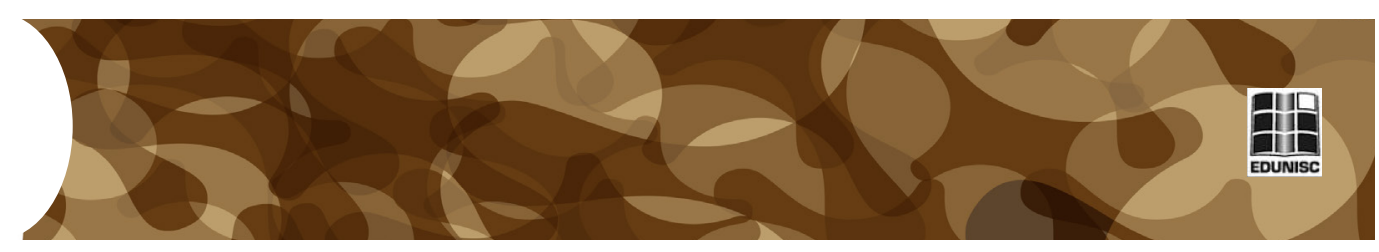

Luíza é o personagem mais forte do núcleo da família. Não é por menos que é ela quem realiza os questionamentos sobre a miséria da família, sua condição social e se opõe ao fanatismo religioso como resposta para isto.

As obras foram realizadas em épocas distintas e estabelecem pressupostos culturais e estéticos de seus tempos. Cada uma destas posturas foi trabalhada de maneira diferente no processo de adaptação. Porém, ambas narrativas estão conectadas como mecanismos que reelaboram o conflito narrativo de Canudos.

Como é evidente, a obra de Euclides possui diversas "camadas de leitura". Além da própria narrativa ficcional, o conflito do ponto de vista histórico, a visão científica que a sociedade tinha do povo em sua época, entre outros. Cada um destes elementos pode constituir adaptações de um processo de uma obra aberta enquanto narrativas específicas.

\section{Conclusão}

A adaptação tomada enquanto articulador de uma obra aberta demonstra como foi redefinido o sentido das experiências dos personagens na narrativa, permitindo distintas conexões interpretativas sobre uma dada realidade com o público. O conceito de obra aberta de Eco (1995) permitiu problematizar a interferência que o processo de adaptação teve na estrutura do foco narrativo, e na expansão de significados, e pontos de vistas pouco explorados pelo autor literário em sua obra, permitindo à obra uma soma da narrativa fílmica e da literatura, ao assumir distintas denotações.

Considerando a afirmação de Mckee (2006), de que o ritmo de consumo de estórias é cada vez maior pela indústria cultural entre as diversas mídias, podemos ponderar que futuramente os universos das obras tendem a se ampliar, tornando-se cada vez mais complexos conforme surgem novas expansões destes universos em decorrência da adaptação na obra aberta como narrativa convergente. Neste sentido, podemos pensar que cada obra finalizada por seu autor é apenas uma narrativa embrionária e o controle dos autores sobre suas obras ao longo do tempo será cada vez menor, deixando a ampliação das obras a cargo tanto da interpretação que seus diversos públicos farão como também dos produtores de mídia.

Assim como as diferentes leituras realizadas pelos públicos nas obras sofrem interferência pelo momento histórico vivido dos leitores, também existe no caso das adaptações na obra aberta uma constante reelaboração das contextualizações de existência destas narrativas pelos produtores de mídia. Desta maneira, a narrativa da obra aberta se desprende de suas amarras do tempo e assume características imprevisíveis. Neste sentido, esta proposta permite indicar a existência de uma problemática para futuros estudos. 


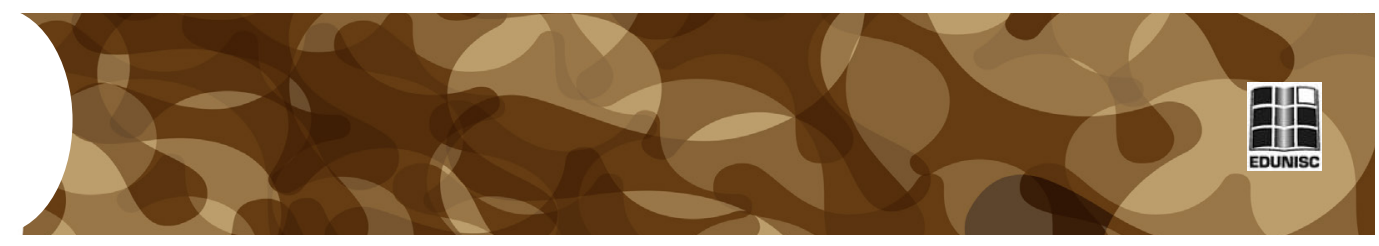

\section{Referências}

A GUERRA de Canudos. Direção: Sérgio Rezende. Produção: José Wilker e Mariza Leão. São Paulo: Columbia Pictures do Brasil, 1997. 1 DVD (169 $\min )$, color.

AGUIAR e SILVA, Vitor Manuel de. A Estrutura do Romance. 3. ed. Coimbra: Livraria Almedina, 1974.

CAMPOS, Flavio de. Roteiro de Cinema e Televisão: A arte e a técnica de imaginar, perceber e narrar uma estória. Rio de Janeiro: Zahar, 2007.

CANDIDO, Antonio; et al. A personagem de ficção. São Paulo: Perspectiva, 1969.

CUNHA, Euclides da. Os sertões. São Paulo: Brasiliense, 1985.

CURY, Maria Zilda Ferreira. Os Sertões: A Nação Ficcionalizada. Caderno de Letras, Belo Horizonte, v.5, p. 231-242, 1997.

DORA M.; LEONE, E. Cinema e Montagem. 2. ed. São Paulo: Ática, 1993.

ECO, Umberto. Obra Aberta. Forma e Indeterminação nas Poéticas Contemporâneas. São Paulo: Perspectiva, 1992.

FLORY, Suely Fadul Villibor. Narrativas ficcionais: da literatura às mídias audiovisuais. São Paulo: Arte \& Ciência, 2005.

FIELD, Syd. Manual do Roteiro. Rio de Janeiro: Objetiva, 2001.

JENKINS, Henry. Cultura da Convergência. São Paulo: Aleph, 2008.

MCKEE, Robert. Story. Substância, Estrutura, Estilo e os Princípios da Escrita de Roteiro. Curitiba: Artes \& Letras, 2006.

MARTIN, Marcel. A linguagem Cinematográfica. Belo Horizonte: Itatiaia, 1963.

METZ, Christian. Linguagem e cinema. São Paulo: Perspectiva, 1980.

MUIR, Edwin. A Estrutura do Romance. 1. ed. Rio de Janeiro: Globo, s/d.

SERGE, Linda. A Arte da Adaptação. Como Transformar fatos e ficção em 


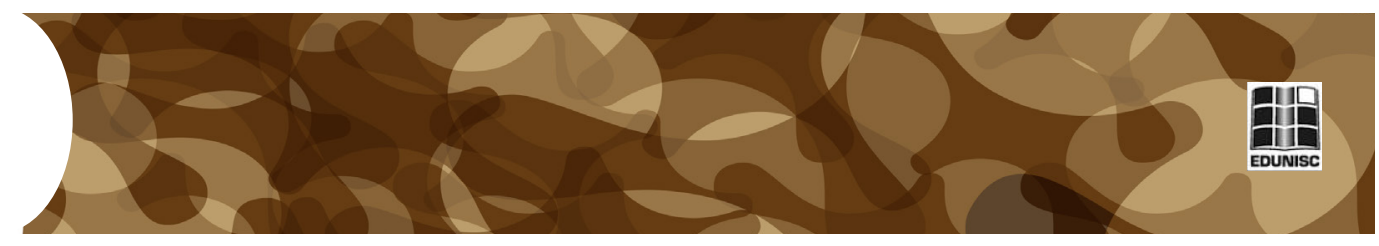

filme. São Paulo: Bossa Nova, 2005.

XAVIER, Ismail et al. Literatura, Cinema e Televisão. São Paulo: Senac São Paulo, 2003.

RIZZO, Talitha Helena Sousa. As formas da adaptação cinematográfica e o narrador Brás Cubas. 2007. Dissertação (Mestrado em Letras) - Curso de Pós-Graduação em Letras, Universidade Presbiteriana Mackenzie, São Paulo, 2007. 